\title{
Comparison of neutrophil to lymphocyte ratio with other prognostic markers affecting 30 day mortality in acute pulmonary embolism
}

\author{
Umut Sabri \\ KASAPOĞLU ${ }^{1}$ \\ Şehnaz OLGUN \\ YILDIZELI ${ }^{1}$ \\ Hüseyin ARIKAN ${ }^{1}$ \\ Ayşen ERER ${ }^{1}$ \\ Feyyaz KABADAYI ${ }^{1}$ \\ Erdem YALÇINKAYA ${ }^{1}$ \\ Melek ASLAN ${ }^{1}$ \\ Nuri Çağatay CiMŞiт ${ }^{2}$ \\ Emel ERYÜKSEL ${ }^{1}$ \\ Sait KARAKURT ${ }^{1}$
}

\footnotetext{
${ }^{1}$ Department of Chest Diseases and Intensive Care, Faculty of Medicine, Marmara University, Istanbul, Turkey

${ }^{1}$ Marmara Üniversitesi Tıp Fakültesi, Göğüs Hastalıkları ve Yoğun Bakım Anabilim Dalı, İstanbul, Türkiye

2 Department of Radiology, Faculty of Medicine, Marmara University, Istanbul, Turkey

${ }^{2}$ Marmara Üniversitesi Tıp Fakültesi, Radyoloji Anabilim Dalı, Istanbul, Türkiye
}

Cite this arcticle as: Kasapoğlu US, Olgun YIldızeli Ş, Arıkan H, Erer A, Kabadayı F, Yalçınkaya E, et al. Comparison of neutrophil to lymphocyte ratio with other prognostic markers affecting 30 day mortality in acute pulmonary embolism. Tuberk Toraks 2019;67(3):179-89.

\section{Yazışma Adresi (Address for Correspondence)}

Dr. Umut Sabri KASAPOĞLU

Marmara Üniversitesi Tıp Fakültesi, Göğüs

Hastalıkları ve Yoğun Bakım Anabilim Dalı,

ISTANBUL - TÜRKIYE

e-mail: umutkasapoglu@gmail.com

OCopyright 2019 by Tuberculosis and Thorax.

Available on-line at www.tuberktoraks.org.com

\section{ABSTRACT}

Comparison of neutrophil to lymphocyte ratio with other prognostic markers affecting $\mathbf{3 0}$ day mortality in acute pulmonary embolism

Introduction: Identifying the prognostic factors for patients with acute pulmonary embolism (APE) play a critical role in determining of the treatment strategy and to reduce mortality. The aim of this study is to evaluate the prognostic value of Neutrophil to Lymphocyte Ratio (NLR) and compare NLR with other prognostic factors in APE.

Materials and Methods: We retrospectively examined 550 cases of acute pulmonary embolism diagnosed by spiral computed tomographic angiography. A receiver operating characteristics (ROC) curve was used to determine the sensitivity and specificity of parameters and the optimal cut-off value for predicting mortality. Significance of each prognostic factors selected by univariate analysis confirmed using Cox regression model.

Results: Baseline NLR, Platelet to Lymphocyte Ratio (PLR), N-terminal proBrain Natriuretic Peptide (NT-proBNP), and D-dimer values respectively were found significantly high in patients who died within 30 days $(p<0.05)$. Patients with high-risk status and SPESI $>2$ points had a significantly higher short-term mortality rate $(p<0.05)$. Short-time mortality was found significantly higher in patients with NLR $>7.3(p<0.05)$. Cox regression analysis indicated that patient risk status and SPESI score were independent prognostic factors $(p<0.05)$. However, NLR was not found as a predictor of mortality in APE ( $p>$ 0.05). After the subgroup analysis of the study, in patients without comorbid diseases NLR, patient's risk status, SPESI score were found the predictor of mortality in APE $(p<0.05)$. 
Conclusion: NLR maybe a useful prognostic factor for patients without comorbid diseases in short time of mortality in APE.

Key words: Pulmonary embolism; neutrophil; lymphocyte; mortality; prognosis

ÖZ

Akut pulmoner embolide nötrofil lenfosit oranının 30 günlük mortaliteyi etkileyen diğer prognostik belirteçler ile karşılaştırılması

Giriş: Akut pulmoner emboli (APE)'de tedavi öncesinde prognostik faktörlerin bilinmesi tedavi stratejilerinin belirlenmesinde ve mortaliteyi azaltmada önemli bir rol oynamaktadır. Bu çalışmada APE'de Nötrofil Lenfosit Oranı (NLR)'nın prognostik değerinin incelenmesi ve diğer prognostik faktörler ile karşılaştırmak amaçlanmıştır.

Materyal ve Metod: Spiral bilgisayarlı tomografi anjiyografi ile APE tanısı konulan 550 olgu retrospektif olarak değerlendirilmiştir. Parametrelerin duyarlılı̆̆ını ve özgüllüğünü tespit etmek ve uygun kesme değerini belirlemek için ROC eğrisi kullanılmıştır. Tek değişkenli analiz ile belirlenmiş olan prognostik faktörlerin çok değişkenli sağkalım analizinde Cox regresyon analizi kullanıldı.

Bulgular: Illk 30 gün içinde ölen olguların tanı anındaki NLR, Trombosit Lenfosit Oranı (PLR), N-terminal pro-Brain Natriüretik Peptid (NT-proBNP), D-Dimer değerleri anlamlı olarak daha yüksek saptandı $(p<0.05)$. Yüksek risk grubundaki hastalar ve sPESI > 2 olan olguların kısa süreli mortalite oranları daha yüksek saptandı $(p<0.05)$. Kısa dönem mortalite NLR > 7.3 olan olgularda anlamlı olarak daha yüksek bulunmuştur $(p<0.05)$. Cox regresyon analizinde hastanın risk durumu ve sPESI mortalite için bağımsız risk faktörü olarak bulunmuştur $(p<0.05)$. Ancak çalışmaya dahil edilen tüm APE olgularında NLR mortalite için bağımsız risk faktörü olarak saptanmamıştır ( $p>0.05$ ). Çalışmanın subgrup analizinde komorbiditesi olmayan APE hastalarında NLR, hastanın risk durumu ve sPESI kısa dönem mortalite için bağımsız risk faktörü olarak bulunmuştur $(p<0.05)$.

Sonuç: Komorbiditesi olmayan APE olgularında NLR kısa süreli mortalite için yararlı bir prognostik faktör olabilir.

Anahtar kelimeler: Pulmoner emboli; nötrofil; lenfosit; mortalite; prognoz

\section{INTRODUCTION}

Even though the development in the medical technology and new treatment strategies, acute pulmonary embolism (APE) is a severe cardiopulmonary disease and also associated with high mortality and morbidity rates, it causes 300.000 deaths in Europe each year, and its short-term mortality rates vary from 2 to $95 \%$ depending on the severity of the disease (1-3). For this reason; identifying the prognostic predictors for patients with APE are crucial to determine the treatment strategy during the acute phase of the disease and to reduce mortality $(4,5)$. For prediction of short-term mortality in acute pulmonary embolism; clinical parameters, imaging of the right ventricle, cardiac or non-cardiac laboratory biomarkers have been used in several studies (4).

Endothelial damage and inflammation play a crucial role in the pathogenesis of APE and hypoxia caused by APE also induce the release of inflammatory cytokines (5). Recent studies show that haematological parameter such as Neutrophil-to-Lymphocyte Ratio (NLR) was a prognostic indicator for inflammatory diseases such as cancer and acute coronary syndrome $(1,5)$. An elevated NLR is also a significant independent predictor of short-term mortality in APE patients $(1,5-7)$.

There are limited data in the literature about the comparison of NLR with other prognostic factors in PE. The aim of this retrospective study was to demon- strate the prognostic value of NLR and compare the NLR with other prognostic factors in patients with APE during the short-term mortality.

\section{MATERIALS and METHODS}

\section{Study Population and Data}

This retrospective cohort study was conducted in Marmara University Hospital between February 2013 and February 2016. Total of 660 patients older than 18 years was diagnosed with acute pulmonary embolism included in the study. Patients with active haematological malignancy, chemotherapy-induced leukopenia, severe renal and liver failure, sepsis and septic shock, acute myocardial infarction and were excluded from the study. After exclusion 550 patients were eligible for the study (Figure 1).

Patients all vital findings, demographical and clinical historical data, the results of laboratory findings were collected from hospital's medical record system (MEDIN 3; version 33.19.909) at the administration of the hospital or daily observations before the diagnosis of APE. NLR was calculated as the ratio of neutrophils to lymphocytes in peripheral blood and Platelet to Lymphocyte Ratio (PLR) was calculated as the ratio of platelets to lymphocytes in peripheral blood.

All cause of short time mortality was defined as the death within 30 days after pulmonary embolism diag- 


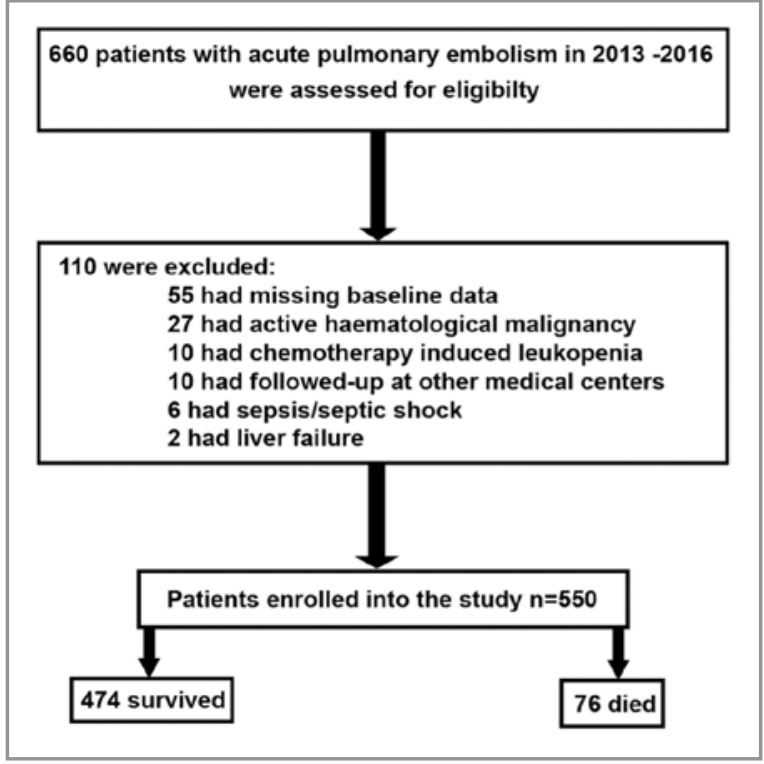

Figure 1. Flowchart of the patients' enrollment.

nosis. Mortality data of patients were collected from the hospital's medical record system and http://obs. gov.tr website.

\section{Definitions}

The simplified Pulmonary Embolism Severity Index (sPESI) scores of patients were calculated using the data obtained from the hospital's medical record system. sPESI assesses six parameters (age $>80$ years, malignancy history, cardiopulmonary disease history, heart rate $>110 / \mathrm{min}$, systolic blood pressure $<100$ $\mathrm{mmHg}$, arterial oxygen saturation $>90 \%$ ). Each positive parameter was scored as 1 point (8).

Hypotension was defined as systolic blood pressure $<90 \mathrm{mmHg}$ or drop of $\geq 40 \mathrm{mmHg}$ from baseline in systolic pressure for longer than 15 minutes if not caused by new-onset arrhythmia, hypovolemia or sepsis. Also, acute pulmonary embolism patients with shock or hypotension were defined as high-risk of death, patients without shock or hypotension were defined as the intermediate or low risk of death (4).

\section{Computed Tomography Imaging}

Diagnosis of APE confirmed by 256-slice scanner spiral computed tomography pulmonary angiography (Somatom Definition Flash, Siemens, Erlangen, Germany) with the detection of pulmonary artery filling the defect. All patients' radiological images evaluated on PACS system (Novapacs, Novarad Corporation, USA) by the radiologist who had an experience in chest radiology.

\section{Statistical Analysis}

The distribution of variables was assessed using the Shapiro Wilk test, and homogeneity using the one-way ANOVA. The distribution of variables was assessed using the Shapiro Wilk test, and homogeneity using the one-way ANOVA. Normal and homogeneous distribution data were presented as mean value \pm standard deviation while data without a normal and homogeneous distribution were shown as median (min-max) values as well as numbers and percentages. A t-test was used for analysis of parametric data, Mann-Whitney $U$ test for analysis of nonparametric data and Chi-square test for analysis of categorical data. Spearman's coefficient of correlation was performed for correlation analysis. A receiver operating characteristics (ROC) curve was used to determine the sensitivity and specificity of the NLR, N-terminal proBrain Natriuretic Peptide (NT-proBNP), D-Dimer and PLR, and the optimal cut off value for the predicting mortality. The survival curve was calculated using the Kaplan-Meier method, and a Log-rank test was used to compare the difference in survival between the groups. Cox regression analysis was used for multivariate survival analysis. The results were analyzed with a confidence level of $95 \%$ and a significance level of $\mathrm{P}<$ 0.05. For statistical analyses, SPSS (Statistical Package for Social Sciences) for Windows 23.0 software (SPSS Inc., Chicago, IL, USA) was used.

\section{Ethics}

The study protocol was approved by the Ethics Committee of Marmara University Medicine (02.11.2018-09.2018.711) and fulfilled the Declaration of Helsinki. The informed consent form was not obtained due to the retrospective nature of the study.

\section{RESULTS}

After exclusion of 110 patients, a total of 550 patients were included in the study. The median age of the patients was 68 (19-86) years, and 277 (50.3\%) of patients were male. Also, $76(13.8 \%)$ patients died within 30 days after the APE diagnosis.

There were significant differences between the survivors and the non-survivors group with respectively age, risk status, gender, sPESI score, haematological parameters, NT-proBNP, D-dimer, and comorbidities $(p<0.05)$. Baseline NLR, PLR, NT-proBNP, and $\mathrm{D}$-dimer values respectively were found significantly higher in patients who died within 30 days $(p=$ 
0.003, $p=0.022, p<0.001, p=0.036)$. Baseline characteristics of the patients are shown in Table 1.

ROC curve analysis performed to find the optimal cut-off value for determining the short-term mortality in APE. ROC curve analysis of NLR to predict mortality is shown in Figure 2. The cut-off values of NLR, PLR, D-dimer, NT-proBNP, and sPESI were found respectively $7.3,170,1.6 \mu \mathrm{g} / \mathrm{mL}, 1300 \mathrm{pg} / \mathrm{mL}$ and

Table 1. Baseline demographical and clinical characteristics of the study patients according to the survival status

\begin{tabular}{|c|c|c|c|c|}
\hline & All patients $(n=550)$ & Survivors $(n=474)$ & Deaths $(n=76)$ & $\mathbf{p}$ \\
\hline Age (years) & $68(19-86)$ & $67(19-86)$ & $73(32-85)$ & $0.017^{\#}$ \\
\hline \multicolumn{5}{|l|}{ Gender } \\
\hline Male & $277(50.3 \%)$ & $229(48.3 \%)$ & $48(63.2 \%)$ & $0.016^{+}$ \\
\hline \multicolumn{5}{|l|}{ Comorbidities } \\
\hline COPD & $141(25.6 \%)$ & $125(26.4 \%)$ & $16(21.1 \%)$ & $0.324^{+}$ \\
\hline $\mathrm{CHF}$ & $61(11 \%)$ & $52(11 \%)$ & $9(11.8 \%)$ & $0.822^{+}$ \\
\hline DM & $83(15 \%)$ & $74(15.6 \%)$ & $9(11.8 \%)$ & $0.394^{+}$ \\
\hline CKD & $15(2.7 \%)$ & $14(3 \%)$ & $1(1.3 \%)$ & $0.416^{+}$ \\
\hline Malignancy & $22(4 \%)$ & $14(3 \%)$ & $8(10.5 \%)$ & $0.002^{+}$ \\
\hline Arrhythmia & $77(14 \%)$ & $74(15.6 \%)$ & $3(3.9 \%)$ & $0.007^{+}$ \\
\hline IHD & $97(17.6 \%)$ & $92(19.4 \%)$ & $5(6.6 \%)$ & $\mathrm{0.006}^{+}$ \\
\hline CVD & $24(4.3 \%)$ & $22(4.6 \%)$ & $2(2.6 \%)$ & $0.426^{+}$ \\
\hline \multicolumn{5}{|l|}{ Risk status } \\
\hline High risk & $70(12.7 \%)$ & $32(7.2 \%)$ & $38(50 \%)$ & $<0.001^{+}$ \\
\hline sPESI score & $1(0-5)$ & $1(0-4)$ & $3(0-5)$ & $<0.001^{\#}$ \\
\hline \multicolumn{5}{|l|}{ CT anjiography findings } \\
\hline MPA diameter (mm) & $29(16-45)$ & $29(16-45)$ & $30(20-42)$ & $0.563^{\#}$ \\
\hline $\mathrm{RV} / \mathrm{LV}>1$ & $191(34.7 \%)$ & $160(33.8 \%)$ & $31(40.8 \%)$ & $0.232^{+}$ \\
\hline \multicolumn{5}{|l|}{ Localization of pulmonary embolism } \\
\hline Main pulmonary artery & $69(12.5 \%)$ & $54(11.4 \%)$ & $15(19.7 \%)$ & $0.037^{+}$ \\
\hline Lobar pulmonary artery & $107(19.5 \%)$ & $89(18.8 \%)$ & $18(23.7 \%)$ & $0.197^{+}$ \\
\hline Segmental pulmonary artery & $259(47.1 \%)$ & $225(47.4 \%)$ & $34(44.7 \%)$ & $0.376^{+}$ \\
\hline Subsegmental pulmonary artery & $136(24.7 \%)$ & $106(22.3 \%)$ & $9(11.8 \%)$ & $\mathbf{0 . 0 2 2}^{+}$ \\
\hline NT-proBNP (pg/mL) & $1292(19-35000)$ & $1060(19-35000)$ & $4106(113-35000)$ & $<0.001^{\#}$ \\
\hline D-dimer $(\mu \mathrm{g} / \mathrm{mL})$ & $1.87(0.04-39.97)$ & $1.71(0.04-39.97)$ & $2.87(0.14-29.4)$ & $0.036^{\#}$ \\
\hline \multicolumn{5}{|l|}{ Haematological parameters } \\
\hline WBC $\left(10^{3} / \mu \mathrm{L}\right)$ & $9.90(1.3-21.8)$ & $9.90(1.7-21.8)$ & $10.20(1.3-20.9)$ & $0.980^{\#}$ \\
\hline $\operatorname{NEU}\left(10^{3} / \mu \mathrm{L}\right)$ & $7.25(0.6-19.5)$ & $7.0(0.6-19.5)$ & $8.20(0.6-17.6)$ & $0.409^{\#}$ \\
\hline $\operatorname{LYM}\left(10^{3} / \mu \mathrm{L}\right)$ & $1.4(0.1-9.1)$ & $1.50(0.1-8.7)$ & $0.95(0.1-9.1)$ & $<0.0011^{\#}$ \\
\hline $\mathrm{HGB}(\mathrm{g} / \mathrm{dL})$ & $12.1 \pm 2.18$ & $12.18 \pm 2.15$ & $11.80 \pm 2.37$ & $0.166^{*}$ \\
\hline HCT (\%) & $37.40(17.2-53.2)$ & $37.50(17.9-52.9)$ & $36.35(17.2-53.2)$ & $0.257^{\#}$ \\
\hline RDW (\%) & $15.3(10.4-33.8)$ & $15.30(10.4-33.8)$ & $15.60(12.6-29.1)$ & $0.049^{\#}$ \\
\hline $\operatorname{PLT}\left(10^{3} / \mu \mathrm{L}\right)$ & $225(22-648)$ & $230(22-648)$ & $209(22-461)$ & $0.041^{\#}$ \\
\hline MPV (fL) & $9.6(5.8-19.3)$ & $9.60(5.8-19.3)$ & $9.70(6.7-19.3)$ & $0.940 \#$ \\
\hline NLR & $7.7(0.37-33.3)$ & $7.60(0.37-23)$ & $8.40(0.55-33.3)$ & $0.003^{\#}$ \\
\hline PLR & $170.2(19.2-2120)$ & $162.31(19.24-2120)$ & $217.22(22.62-1570)$ & $0.022^{\#}$ \\
\hline
\end{tabular}

COPD: Chronic obstructive pulmonary disease, CHF: Chronic heart failure, DM: Diabetes mellitus, CKD: Chronic kidney disease, IHD: Ischemic heart disease, CVD: Cerebrovascular disease, sPESI: Simplified pulmonary embolism prognostic index, RV: Right ventricle, LV: Left ventricle, NT-proBNP: N-terminal prohormone of brain natriuretic peptide, WBC: White blood cell, NEU: Neutrophil, LYM: Lymphocyte, HGB: Hemoglobin, HCT: Hematocrit, RDW: Red cell distribution width, PLT: Platelets, MPV: Mean platelet volume, NLR: Neutrophil to lymphocyte ratio, PLR: Platelet to lymphocyte ratio, CT: Computed tomography, MPA: Main pulmonary artery.

\# Mann-Whitney U test, ${ }^{+}$Chi-Square test, * Independent Sample T-Test. 


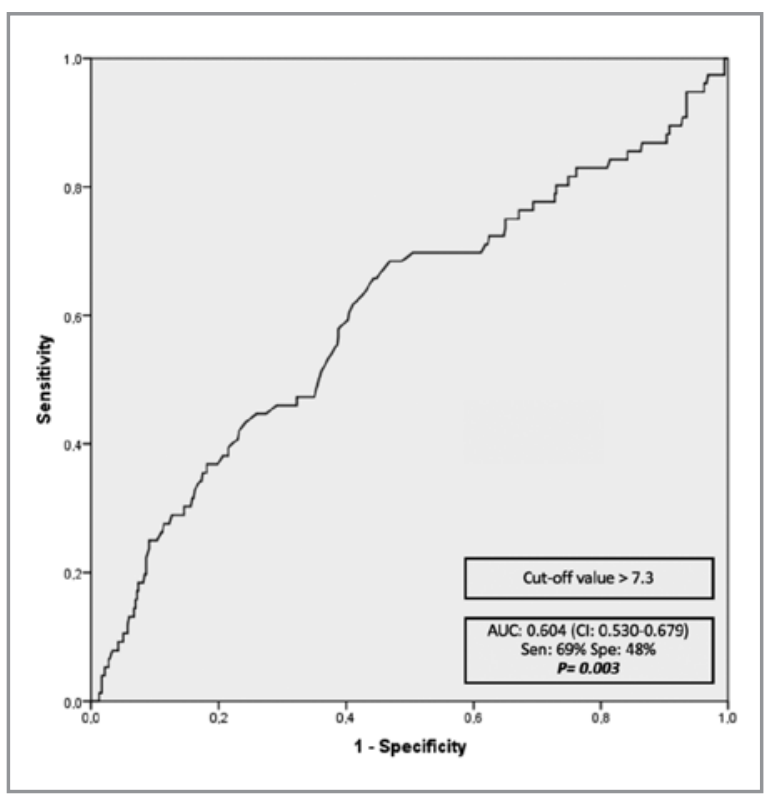

Figure 2. Receiver operator characteristics curve of NLR to predict mortality.
Table 3. Values of sensitivity and specificity for the optimal cut-off point of NLR for predicting 30 day mortality among patients with acute pulmonary embolism

\begin{tabular}{|lcc|}
\hline Sensitivity & Specificity & Cut-off point \\
\hline $100 \%$ & $0.4 \%$ & 0.50 \\
$94.7 \%$ & $3.8 \%$ & 1.70 \\
$90.8 \%$ & $6.5 \%$ & 2.03 \\
$85.5 \%$ & $13.7 \%$ & 2.85 \\
$80.3 \%$ & $25.1 \%$ & 4.32 \\
$75.0 \%$ & $32.9 \%$ & 5.51 \\
$71.1 \%$ & $38.2 \%$ & 6.58 \\
$\mathbf{6 9 . 7} \%$ & $\mathbf{4 7 . 5} \%$ & 7.33 \\
$61.8 \%$ & $48.9 \%$ & 8.05 \\
$55.3 \%$ & $51.4 \%$ & 8.26 \\
$51.3 \%$ & $53.9 \%$ & 8.35 \\
$44.7 \%$ & $63.8 \%$ & 8.91 \\
$40.8 \%$ & $67.0 \%$ & 9.15 \\
\hline & & \\
\hline
\end{tabular}

Table 2. Values of AUC, sensitivity and specificity for the optimal cut-off value of sPESI, NT-proBNP, D-Dimer, NLR and PLR for the prediction of short term mortality in acute pulmonary embolism

\begin{tabular}{lccccc}
\hline Predictors & AUC $(\mathbf{9 5} \% \mathbf{C l})$ & $\mathbf{p}$ & Cut-off & Sensitivity & Specificity \\
\hline SPESI & $0.895(0.859-0.932)$ & $<0.001$ & 2 & $84 \%$ & $89 \%$ \\
NT-proBNP & $0.710(0.634-0.786)$ & $<0.001$ & 1300 & $71 \%$ & $54 \%$ \\
D-dimer & $0.627(0.509-0.744)$ & 0.036 & 1.6 & $66 \%$ & $58 \%$ \\
NLR & $0.604(0.530-0.679)$ & 0.003 & 170 & $69 \%$ & $48 \%$ \\
PLR & $0.582(0.502-0.661)$ & 0.022 & $63 \%$ & $53 \%$ \\
\hline
\end{tabular}

NT-proBNP: N-terminal prohormone of brain natriuretic peptide, NLR: Neutrophil to lymphocyte ratio, sPESI: Simplified pulmonary embolism prognostic index, PLR: Platelet to lymphocyte ratio, $\mathrm{Cl}$ : Confidence interval, AUC: Area under curve, Cl: Confidence interval.

three for the determining the short-term mortality in APE (Table 2). Values of sensitivity and specificity for the optimal cut-off point of NLR for predicting 30 day mortality are shown in Table 3 .

The correlation analysis shown that, NLR values were weakly positive correlated with sPESI score $(r=$ $0.100, p=0.01)$ and NT-proBNP $(r=0.232, p<0.001)$ respectively. Correlation between NLR and other prognostic factors is shown in Table 3.

Prognostic factors affecting the short time mortality in APE with the univariate analysis are shown in Table 4. Patients with high-risk status and sPESI $>2$ points had a significantly higher short-term mortality rate $(p<0.001, p<0.001)$ (Figure 3). Also, short-time mortality was found significantly higher in patients with NLR $>7.3$, PLR $>170(p=0.011, p=0.013)$. After the univariate analyses of prognostic factors affecting the short-time survival of APE, multivariate Cox regression model was performed for the independent prognostic factors. It is shown that only patient risk status (HR: 2.83, 95\% Cl: 1.96-8.35) and sPESI score (HR: 28.33, 95\% Cl: 5.88-55.36) were significant and independent prognostic factors of short-term mortality in APE $(p=0.038, p<0.001)$. However, our study indicated that NLR was not the predictor of the mortality in APE $(p=0.669)$ (Table 5).

In the subgroup analysis of the study, the total of 181 patients without comorbid diseases have been evaluated. ROC curve analysis performed again to find the optimal cut-off value for determining the short-term mortality. The cut-off values of NLR, NT-proBNP, and sPESI were found respectively 7.3 (AUC: $0.677,95 \%$ 


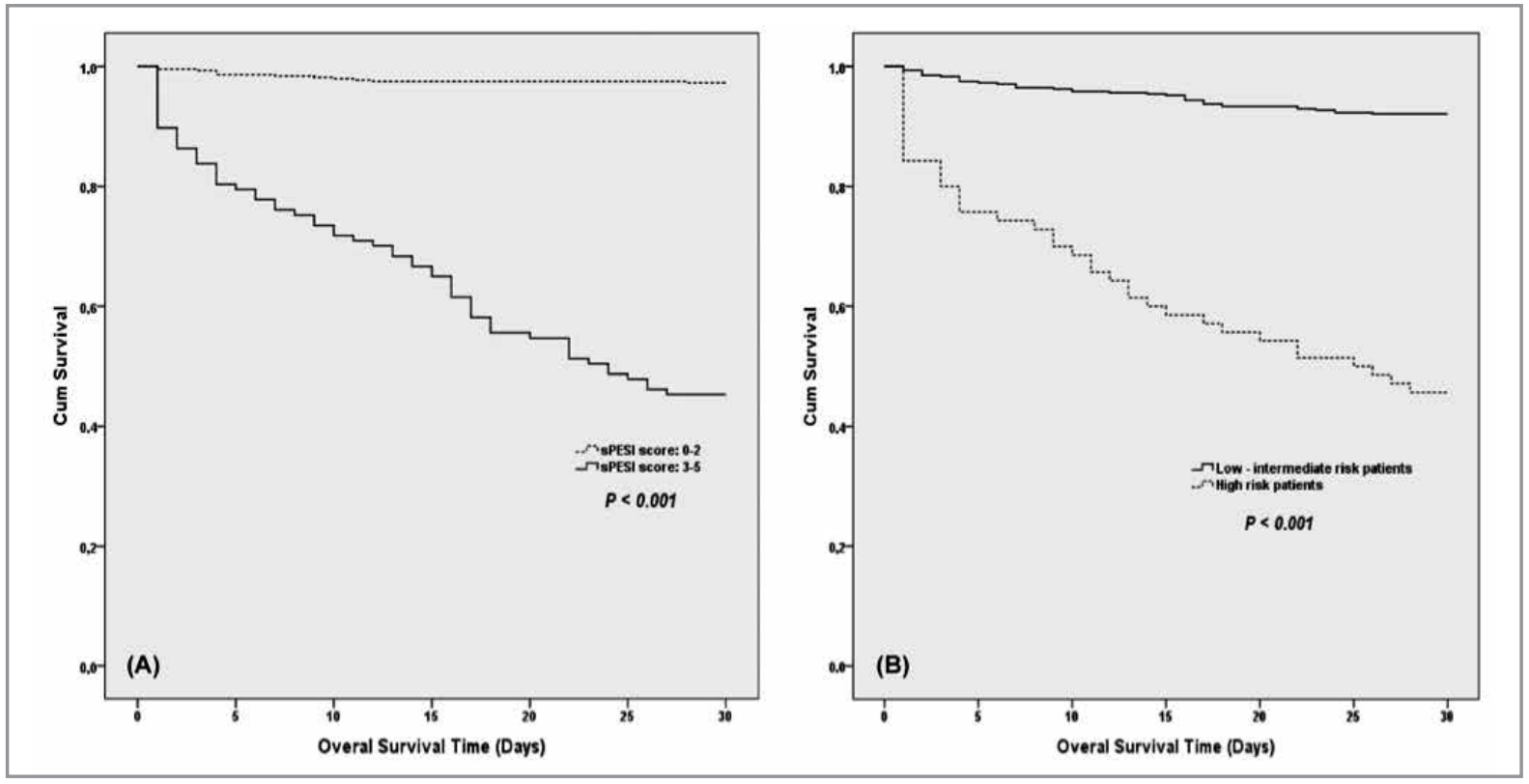

Figure 3. Kaplan-Meier curves of overall survival time for acute pulmonary embolism patient by (A) sPESI score, (B) patient risk status. $\mathrm{p}$ values were calculated the Log-rank test. sPESI: Simplified pulmonary embolism prognostic index.

Table 4. The correlation analysis of NLR with other prognostic factors*

\begin{tabular}{|lcc|}
\hline & Correlation coefficient & p \\
\hline NT-proBNP & 0.232 & $\mathbf{0 . 0 1}$ \\
sPESI & 0.100 & $\mathbf{0 . 0 2}$ \\
D-dimer & 0.111 & 0.065 \\
\hline $\begin{array}{l}\text { NLR: Neutrophil-to-lymphocyte ratio, NT-proBNP: N-terminal pro- } \\
\text { hormone of brain natriuretic peptide, sPESI: Simplified pulmonary } \\
\text { embolism prognostic index. } \\
* \text { Spearman's correlation analysis test. }\end{array}$ \\
\hline
\end{tabular}

$\mathrm{Cl}: 0.580-0.775, \quad \mathrm{p}=0.001), 1100 \mathrm{pg} / \mathrm{mL} \quad(\mathrm{AUC}$ : 0.797, 95\% Cl: 0.697-0.897, p<0.001) and 3 (AUC: $0.873,95 \% \mathrm{Cl}: 0.812-0.934, \mathrm{p}<0.001)$ for the determining the short-term mortality in APE. Also, NLR values were positively correlated with sPESI score $(r=$ $0.160, p=0.016$ ), on the other hand NLR values did not correlate with NT-proBNP $(p=0.072)$. In univariate analysis have been shown that patients' with high risk status, sPESI $\geq 3$ points, NLR $>7.3$ and NT-proBNP $>1100 \mathrm{pg} / \mathrm{mL}$ had a significantly higher short-term mortality rate respectively $(p<0.001, p<0.001, p=$ $0.003, p<0.001)$. In patients without comorbid diseases NLR, patient's risk status, sPESI score were found the predictor of the mortality in APE $(p=0.016$, $p=0.026, p<0.001$ ) (Table 6).

\section{DISCUSSION}

The present study has been shown that; patients' risk status and SPESI score are the prognostic factors for the short-time mortality in APE patients with or without comorbid disease, whereas NLR is the independent prognostic predictor only in patients without comorbid diseases.

APE presents with wide symptoms and findings in the clinical practice. For this reason, identifying the prognostic factors affecting mortality for the management of treatment and/or early prediction of prognosis are crucial in APE patients. Numerous factors affecting the prognosis of patients with APE have been described in studies including the clinical, radiological and laboratory parameters (4,9-11).

Clinical parameters such as cancer, chronic obstructive pulmonary disease (COPD), chronic heart failure, age $>70$ years were all associated with increased risk of death in acute pulmonary embolism patients $(12,13)$. Not surprisingly, it has been shown that patients over 70 years old, patients with comorbidities such as cancer, ischemic heart disease and arrhythmia had an increased mortality in the present study. However, chronic heart failure and COPD were not found associated with increased mortality. 


\section{Table 5. Effect of prognostic factors on survival time in APE}

\begin{tabular}{|c|c|c|c|c|}
\hline & $\begin{array}{l}\text { Mean survival time } \\
\quad(\text { days } \pm \mathrm{SE})\end{array}$ & Lower bound & Upper bound & p \\
\hline \multicolumn{5}{|l|}{ sPESI score } \\
\hline $0-2$ points & $29.38 \pm 0.18$ & 29.02 & 29.74 & $<0.001$ \\
\hline 3-5 points & $19.55 \pm 1.04$ & 17.50 & 21.60 & \\
\hline \multicolumn{5}{|l|}{ NLR level } \\
\hline$>7.3$ & $28.09 \pm 0.41$ & 27.29 & 28.89 & 0.011 \\
\hline$\leq 7.3$ & $26.67 \pm 0.46$ & 25.76 & 27.57 & \\
\hline \multicolumn{5}{|l|}{ PLR level } \\
\hline$>170$ & $26.62 \pm 0.49$ & 25.66 & 27.58 & 0.013 \\
\hline$\leq 170$ & $27.96 \pm 0.39$ & 27.18 & 28.73 & \\
\hline \multicolumn{5}{|l|}{ Comorbidity } \\
\hline Present & $25.91 \pm 0.64$ & 24.65 & 27.17 & $<0.001$ \\
\hline Absent & $27.29 \pm 0.34$ & 27.29 & 28.64 & \\
\hline \multicolumn{5}{|l|}{ Risk status } \\
\hline High risk & $18.97 \pm 1.42$ & 16.17 & 21.77 & $<0.001$ \\
\hline Low-intermediate risk & $28.50 \pm 0.25$ & 28.01 & 29.03 & \\
\hline \multicolumn{5}{|l|}{ NT-proBNP level } \\
\hline$>1300 \mathrm{pg} / \mathrm{mL}$ & $25.57 \pm 0.70$ & 24.19 & 26.96 & 0.001 \\
\hline$\leq 1300 \mathrm{pg} / \mathrm{mL}$ & $28.46 \pm 0.42$ & 27.63 & 29.29 & \\
\hline \multicolumn{5}{|l|}{ D-dimer level } \\
\hline$>1.6$ & $26.07 \pm 0.84$ & 24.43 & 27.72 & 0.015 \\
\hline$\leq 1.6$ & $28.72 \pm 0.51$ & 27.70 & 29.73 & \\
\hline \multicolumn{5}{|l|}{ Gender } \\
\hline Male & $26.85 \pm 0.46$ & 25.94 & 27.76 & 0.020 \\
\hline Female & $27.74 \pm 0.42$ & 26.90 & 28.57 & \\
\hline \multicolumn{5}{|l|}{ Malignancy } \\
\hline Present & $22.09 \pm 2.48$ & 17.23 & 26.95 & 0.001 \\
\hline Absent & $27.51 \pm 0.30$ & 26.90 & 28.11 & \\
\hline \multicolumn{5}{|l|}{ Thrombus in main PA } \\
\hline Present & $25.40 \pm 1.16$ & 23.12 & 27.68 & 0.033 \\
\hline Absent & $27.56 \pm 0.31$ & 26.94 & 28.19 & \\
\hline \multicolumn{5}{|l|}{ Arrhythmia } \\
\hline Absent & $29.03 \pm 0.55$ & 27.95 & 30.12 & 0.008 \\
\hline Present & $27.01 \pm 0.35$ & 26.31 & 27.70 & \\
\hline \multicolumn{5}{|l|}{$\mathrm{CHD}$} \\
\hline Absent & $28.93 \pm 0.49$ & 27.97 & 29.89 & 0.008 \\
\hline Present & $26.94 \pm 0.36$ & 26.22 & 27.66 & \\
\hline \multicolumn{5}{|c|}{$\begin{array}{l}\text { APE: Acute pulmonary embolism, PLR: Platelets-to-lymphocyte ratio, PA: Pulmonary artery, NT-proBNP: N-terminal prohormone of brain natriuretic } \\
\text { peptide, NLR: Neutrophil-to-lymphocyte ratio, sPESI: Simplified pulmonary embolism prognostic index, CHD: Coronary heart disease, CI: } \\
\text { Confidence interval, SE: Standard error. } \\
\text { * By Log-rank test. }\end{array}$} \\
\hline
\end{tabular}


Table 6. Multivariate Cox regression analysis of results of short-term mortality for acute pulmonary embolism

\begin{tabular}{|lcccc|}
\hline Risk factors & HR & Lower bound & U5\% $\mathbf{C l}$ & $\mathbf{p}$ \\
\hline sPESI & $\mathbf{2 8 . 3 3}$ & 5.88 & 55.36 & $<\mathbf{0 . 0 0 1}$ \\
High risk patient & $\mathbf{2 . 8 3}$ & 1.96 & 8.35 & $\mathbf{0 . 0 3 8}$ \\
NLR & 1.27 & 0.42 & 3.84 & 0.669 \\
PLR & 1.40 & 0.51 & 3.82 & 0.503 \\
NT-proBNP & 0.51 & 0.20 & 1.31 & 0.164 \\
Malignancy & 1.78 & 0.41 & 7.76 & 0.441 \\
\hline HR: Hazard ratio, PLR: Platelets-to-lymphocyte ratio, NT-proBNP: N-terminal prohormone of brain natriuretic peptide, NLR: Neutrophil-to- \\
lymphocyte ratio, sPESI: Simplified pulmonary embolism prognostic index, Cl: Confidence interval.
\end{tabular}

Table 7. Results of multivariate Cox regression analysis of univariate survival factors in acute pulmonary embolism patients without comorbidities

\begin{tabular}{|c|c|c|c|c|c|c|}
\hline & \multicolumn{3}{|c|}{ Univariate analysis } & \multicolumn{3}{|c|}{ Multivariate analysis } \\
\hline & OST (days) & $95 \% \mathrm{Cl}$ & $\mathbf{p}$ & HR & $95 \% \mathrm{Cl}$ & $\mathbf{p}$ \\
\hline \multicolumn{7}{|l|}{ Risk status } \\
\hline High risk & $17.67 \pm 2.04$ & $13.67-21.68$ & $<0.001$ & 2.76 & $1.12-6.79$ & 0.026 \\
\hline Low-intermediate risk & $27.62 \pm 0.55$ & $26.53-28.70$ & & & & \\
\hline \multicolumn{7}{|l|}{ sPESI score } \\
\hline$\geq 3$ points & $19.28 \pm 1.47$ & $16.38-22.18$ & $<0.001$ & 15.96 & $3.45-73.81$ & $<0.001$ \\
\hline$<3$ points & $28.66 \pm 0.49$ & $27.69-29.63$ & & & & \\
\hline \multicolumn{7}{|l|}{ NLR } \\
\hline$>7.3$ & $24.44 \pm 0.91$ & $22.64-26.24$ & 0.003 & 3.30 & $1.24-8.74$ & 0.016 \\
\hline$\leq 7.3$ & $28.30 \pm 0.68$ & 26.96-29.64 & & & & \\
\hline \multicolumn{7}{|l|}{ NT-proBNP } \\
\hline$>1100 \mathrm{pg} / \mathrm{mL}$ & $23.49 \pm 1.37$ & 20.78-26.19 & $<0.001$ & 0.22 & $0.07-0.66$ & 0.073 \\
\hline$\leq 1100 \mathrm{pg} / \mathrm{mL}$ & $28.70 \pm 0.68$ & 27.36-30.05 & & & & \\
\hline
\end{tabular}

More importantly, shock or hypotension is a crucial prognostic factor in APE and presence of shock or hypotension in patients with APE have been defined as a high risk of mortality $(4,11)$. Persistent hypotension has been also described the sign of acute Right Ventricle (RV) dysfunction. Detection of RV dysfunction on echocardiography has been associated with increased mortality and early complications in APE patients. Therefore, early detection of RV dysfunction with echocardiography may be helpful for detecting the high-risk patients $(4,11,14,15)$. RV dysfunction findings on computed tomography angiography such RV enlargement and increased RV/LV ratio have been found associated with increased mortality. Also, central localization of embolism in pulmonary artery was associated with increased risk of short-term mortality and it was confirmed in the present study $(4,15-$ 18). Due to retrospective design of the present study, lots of patients' echocardiography data and RV dysfunction findings have not been evaluated. Also, relation between increased RV/LV ratio and mortality were not confirmed in the present study.

Laboratory biomarkers as the prognostic factor for mortality in APE can be classified cardiac and non-cardiac biomarkers. NT-proBNP, Brain Natriuretic Peptide (BNP), cardiac troponin I or $\mathrm{T}$ and Heart-type fatty acid-binding protein (H-FABP) are the cardiac prognostic biomarkers, D-dimer is the non cardiac prognostic biomarker for the short-term mortality in APE (4). NT-proBNP which is released from the ventricles in response to cardiac myocyte stretch and cardiac ventricle wall tension, has found to be strong prognostic factor of morbidity and mortality in patients with heart failure. It has been also significantly associated with increased risk for short- 
term mortality and complications in APE patients. Also, the increase in plasma NT-proBNP levels is related to the severity of hemodynamic status and RV dysfunction. On the other hand, low levels of plasma NT-proBNP have been found to have a highly negative predictive value for early poor prognosis in acute pulmonary embolism $(4,19-21)$. In the present study, level of plasma NT-proBNP was found higher in patients died within 30 days, also NT-proBNP was shown as risk factor for short term mortality in univariate analysis but was not found significantly independent risk factor in multivariate analysis. D-dimer as a non-cardiac biomarker and mortality relation has been evaluated in some studies for acute pulmonary embolism patients. These studies shown that increased level of plasma D-dimer were associated with increased short-term mortality, and it has been confirmed in the present study $(4,22,23)$. However, it was not found as a significantly independent risk factor in multivariate analysis.

sPESI which has been developed by Jimenez and colleagues has found to be strong prognostic factor for short- or long-term mortality in APE. Morever, several studies and meta-analyses reported the accuracy of sPESI scoring in predicting short- or long-term mortality in APE patients $(4,8,24,25)$. Similar to these studies, high sPESI score was found to be the most important independent prognostic factor for the short-term mortality in the present study.

Hematologic parameters can be used to predict mortality and determine the clinical severity in APE patients. Hematologic parameters are inexpensive and easily measurable laboratory factors in clinical practice $(26,27)$. More recently, Zhou et al. showed that high red cell distribution width (RDW) can be a simple and useful prognostic factor in APE patients (28). Also, RDW can be used with PESI for the risk stratification of APE patients (29). Similarly, we found that RDW levels were higher in patients died within 30 days after the diagnosis of APE. In addition, mean platelet volume (MPV) can be used for diagnosis of venous thromboembolism, prediction of pulmonary embolism recurrence and mortality. Moreover, MPV has been associated with right ventricular dysfunction in APE patients $(30,31)$. In the present study, MPV levels were higher in patients died within 30 days after the diagnosis of APE, however it was not statistically significant.
Severe hypoxia associated with pulmonary artery embolism and venous thromboembolism cause the release of inflammatory cytokines. For this reason, inflammation plays an important role in pulmonary embolism $(1,5,32)$. Also, Kurtipek et al. found that NLR and PLR values can be associated with endothelial dysfunction in patients with pulmonary embolism (33). Recent studies showed that NLR and PLR were found to be a better inflammatory biomarker compared with white blood cell count.

Studies and meta-analysis have shown that higher levels of PLR were associated with increased mortality in APE patients, for this reason it can be used as a promising biomarker for predicting mortality $(1,5,32)$. In the present study, increased level of PLR was associated with poor survival in APE patients. However, PLR was not found as an independent prognostic factor.

Increased level of NLR was also associated with higher level of inflammation and poor prognosis of diseases $(1,32)$. NLR was the independent prognostic factor for mortality in cardiovascular diseases, cancer and many inflammatory diseases $(1,32,34)$. Recent studies which was evaluated relation between prognosis of APE and the NLR showed that NLR was an independent prognostic factor for mortality in APE and may be useful biomarker for the identifying high risk patients $(1,5,6,32,34)$. In these studies, the optimal cutoff values of NLR for short-time mortality have been found to be shown variabilities, and cutoff values have varied from 5.70 to 9.2. Patients' different demographical characteristics such as comorbitidies have been thought to be the cause of this situation $(5,6,26,34)$. Patients with or without comorbidities' cutoff value of NLR for short-time mortality was determined as 7.3 in the present study. Not surprisingly we found that increased level of NLR was associated with poor prognosis in APE patients. However, NLR was not found as an independent prognostic factor in multivariate analysis for all APE patients. After exclusion of patients with comorbidities subgroup analysis was performed, we found that NLR was the important independent risk factor for patients without comorbidities in acute pulmonary embolism. Also, we found the significantly positive correlation between NLR and SPESI score.

\section{LIMITATIONS}

Our study had some limitations. Our study is a single center retrospective cohort study. Cardiac troponin 
which is considered prognostic biomarker for APE and patients' echocardiography reports were not evaluated in the study.

\section{CONCLUSION}

In conclusion, even though the high level of NLR is related with short-term mortality, multivariate analysis indicates that NLR is not an independent prognostic factor of short-time mortality in all APE patients. However, subgroup analysis has been indicated that NLR is an important independent prognostic factor for patients without comorbid diseases in short-time mortality, and increased level of NLR is related with 3.3-fold higher risk for short-term mortality. Therefore, we suggest the use of NLR for identifying the highrisk APE patients without comorbidities, due to it is a cheap, simple and easy to perform laboratory test.

\section{CONFLICT of INTEREST}

No conflict of interest declared by the authors.

\section{AUTHORSHIP CONTRIBUTIONS}

Concept/Design: USK, SK, HA, ŞOY

Analysis/Interpretation: USK, HA

Data Acquisition: AE, FK, EY, NÇC, MA

Writting: USK, HA, AE, FK, EY

Critical Revision: All of authors.

Final Approval: All of authors.

\section{REFERENCES}

1. Wang Q, Ma J, Jiang Z, Ming L. Prognostic value of neutrophil-to-lymphocyte ratio and platelet-to-lymphocyte ratio in acute pulmonary embolism: a systematic review and meta-analysis. Int Angiol 2018;37:4-11.

2. Cohen AT, Agnelli G, Anderson FA, Arcelus II, Bergqvist D, Brecht JG, et al. Venous thromboembolism (VTE) in Europe. The number of VTE events and associated morbidity and mortality. Thromb Haemost 2007;98:756-64.

3. Aujesky D, Obrosky DS, Stone RA, Auble TE, Perrier A, Cornuz J, et al. A prediction rule to identify low-risk patients with pulmonary embolism. Arch Intern Med 2006; 166:169-75.

4. Konstantinides SV, Torbicki A, Agnelli G, Danchin N, Fitzmaurice D, Galiè N, et al. Task Force for the Diagnosis and Management of Acute Pulmonary Embolism of the European Society of Cardiology (ESC). 2014 ESC guidelines on the diagnosis and management of acute pulmonary embolism. Eur Heart J 2014;35:3033-69.
5. Ma Y, Mao Y, He X, Sun Y, Huang S, Qiu J. The values of neutrophil to lymphocyte ratio and platelet to lymphocyte ratio in predicting 30 day mortality in patients with acute pulmonary embolism. BMC CardiovasC Disord 2016; 16:123.

6. Kayrak M, Erdoğan HI, Solak Y, Akilli H, Gül EE, Yildirim O, et al. Prognostic value of neutrophil to lymphocyte ratio in patients with acute pulmonary embolism: a restrospective study. Heart Lung Circ 2014;23:56-62.

7. Kundi $H$, Balun A, Cicekcioglu $H$, Cetin M, Kiziltunc E, Cetin ZG, et al. The relation between platelet-to-lymphocyte ratio and Pulmonary Embolism Severity Index in acute pulmonary embolism. Heart Lung 2015;44:340-3.

8. Jiménez $D$, Aujesky D, Moores L, Gómez V, Lobo IL, Uresandi $F$, et al. Simplification of the pulmonary embolism severity index for prognostication in patients with acute symptomatic pulmonary embolism. Arch Intern Med 2010;170:1383-9.

9. Donadini MP, Dentali F, Castellaneta $M$, Gnerre P, La Regina $M$, Masotti L, et al. Pulmonary embolism prognostic factors and length of hospital stay: a cohort study. Thromb Res 2017; 156:155-9.

10. Elias A, Mallett S, Daoud-Elias M, Poggi JN, Clarke M. Prognostic models in acute pulmonary embolism: a systematic review and meta-analysis. BMJ Open 2016;6:e010324.

11. Chodakowski JD, Courtney DM. Pulmonary embolism critical care update: prognosis, treatment, and research gaps. Curr Opin Crit Care 2018;24:540-6.

12. Laporte S, Mismetti P, Décousus H, Uresandi F, Otero R, Lobo $L$, et al. RIETE Investigators. Clinical predictors for fatal pulmonary embolism in 15,520 patients with venous thromboembolism: findings from the Registro Informatizado de la Enfermedad TromboEmbolica venosa (RIETE) Registry. Circulation 2008;117:1711-6.

13. Goldhaber SZ, Visani L, De Rosa M. Acute pulmonary embolism: clinical outcomes in the International Cooperative Pulmonary Embolism Registry (ICOPER). Lancet 1999;353:1386-9.

14. Barco S, Mahmoudpour SH, Planquette B, Sanchez O, Konstantinides SV, Meyer G. Prognostic value of right ventricular dysfunction or elevated cardiac biomarkers in patients with low-risk pulmonary embolism: a systematic review and meta-analysis. Eur Heart J 2018.

15. Zhu L, Yang $Y, W u Y$, Zhai Z, Wang $C$. Value of right ventricular dysfunction for prognosis in pulmonary embolism. Int J Cardiol 2008;127:40-5.

16. Vedovati MC, Germini F, Agnelli G, Becattini C. Prognostic role of embolic burden assessed at computed tomography angiography in patients with acute pulmonary embolism: systematic review and meta-analysis. J Thromb Haemost 2013:11:2092-102. 
17. Choi KJ, Cha SI, Shin KM, Lim JK, Yoo SS, Lee J, et al. Central emboli rather than saddle emboli predict adverse outcomes in patients with acute pulmonary embolism. Thromb Res 2014;134:991-6.

18. Becattini C, Agnelli G, Germini F, Vedovati MC. Computed tomography to assess risk of death in acute pulmonary embolism: a meta-analysis. Eur Respir J 2014;43:1678-90.

19. Pasha SM, Klok FA, van der Bijl N, de Roos A, Kroft LJ, Huisman MV. NT-pro-BNP levels in patients with acute pulmonary embolism are correlated to right but not left ventricular volume and function. Thromb Haemost 2012;108:367-72.

20. Verschuren $F$, Bonnet $M$, Benoit MO, Gruson D, Zech $F$, Couturaud $F$, et al. The prognostic value of pro-B-Type natriuretic peptide in acute pulmonary embolism. Thromb Res 2013;131:e235-9.

21. Bajaj A, Rathor P, Sehgal V, Kabak B, Shetty A, Al Masalmeh $O$, et al. Prognostic value of biomarkers in acute non-massive pulmonary embolism: A systematic review and meta-analysis. Lung 2015;193:639-51.

22. Becattini C, Lignani A, Masotti L, Forte MB, Agnelli G. $D$-dimer for risk stratification in patients with acute pulmonary embolism. J Thromb Thrombolysis 2012;33:48-57.

23. Aujesky D, Roy PM, Guy M, Cornuz J, Sanchez O, Perrier A. Prognostic value of $D$-dimer in patients with pulmonary embolism. Thromb Haemost 2006;96:478-82.

24. Zhou XY, Ben SQ, Chen HL, Ni SS. The prognostic value of pulmonary embolism severity index in acute pulmonary embolism: a meta-analysis. Respir Res 2012;13:111.

25. Kilic T, Gunen H, Gulbas G, Hacievliyagil SS, Ozer A. Prognostic role of simplified Pulmonary Embolism Severity Index and the European Society of Cardiology Prognostic Model in short and long-term risk stratification in pulmonary embolism. Pak J Med Sci 2014;30:1259-64.

26. Ates H, Ates I, Kundi H, Yilmaz FM. Diagnostic validity of hematologic parameters in evaluation of massive pulmonary embolism. J Clin Lab Anal 2017;31.
27. Akgüllü Ç, Ömürlü iK, Eryılmaz U, Avcil M, Dağtekin E, Akdeniz $M$, et al. Predictors of early death in patients with acute pulmonary embolism. Am J Emerg Med 2015;33:214-21

28. Zhou $X Y$, Chen HL, Ni SS. Red cell distribution width in predicting 30-day mortality in patients with pulmonary embolism. J Crit Care 2017;37:197-201.

29. Jurin I, Trkulja V, Ajduk M, Letilović T, Hadžibegović I. Red cell distribution width in acute pulmonary embolism patients: a simple aid for improvement of the 30-day mortality risk stratification based on the pulmonary embolism severity index. Heart Lung 2019. pii: S01479563(18)30379-0.

30. Kostrubiec M, Łabyk A, Pedowska-Włoszek J, HrynkiewiczSzymańska A, Pacho S, Jankowski K, et al. Mean platelet volume predicts early death in acute pulmonary embolism. Heart 2010;96:460-5.

31. Araz O, Albez FS, Ucar EY, Kerget B, Yılmaz N, Akgun M. predictive value of mean platelet volume for pulmonary embolism recurrence. Lung 2017;195:497-502.

32. Karataş MB, Ipek G, Onuk T, Güngör B, Durmuş G, Çanga $Y$, et al. Assessment of prognostic value of neutrophil to lymphocyte ratio and platelet to lymphocyte ratio in patients with pulmonary embolism. Acta Cardiol Sin 2016;32:313-20

33. Kurtipek E, Büyükterzi Z, Büyükterzi M, Alpaydın MS, Erdem SS. Endothelial dysfunction in patients with pulmonary thromboembolism: neutrophil to lymphocyte ratio and platelet to lymphocyte ratio. Clin Respir J 2017;11:7882.

34. Soylu K, Gedikli Ö, Ekşi A, Avcıoğlu Y, Soylu Al, Yüksel S, et al. Neutrophil-to-lymphocyte ratio for the assessment of hospital mortality in patients with acute pulmonary embolism. Arch Med Sci 2016;12:95-100. 